\section{Market-driven health care mess: the United States}

\author{
O emaranhado da assistência à saúde movida pelo \\ mercado: o caso dos Estados Unidos
}

\author{
La maraña de la atención sanitaria impulsada por \\ el mercado: el caso de EE.UU.
}

1 Dalla Lana School of Public Health, University of Toronto, Toronto, Canada.

2 Physicians for a National

Health Program, Chicago,

U.S.A.

Correspondence

A.-E. Birn

Dalla Lana School of Public

Health, University of Toronto.

155 College St, Rm 558,

Toronto / Ontario - M5S 2L6,

Canada.

ae.birn@utoronto.ca
It is difficult to speak of a health care system in the United States. Even after the passage of major health reform in 2010, the Patient Protection and Affordable Care Act (ACA), known as "Obamacare", the U.S. has the world's most expensive, bureaucratic, and inequitable health system 1 . While the United States delivers some of the most technologically advanced medicine and is a medical research leader, it ranks last out of 11 wealthy countries in terms of mortality amenable to medical care, infant mortality, and life expectancy at age 602 . In addition to delivering poor outcomes, health care in the U.S. is far more expensive than in any other country. In 2014, U.S. health care spending totaled a whopping US $\$ 3.1$ trillion, US\$ 9,694/person, more than $17.7 \%$ of its Gross domestic product (GDP), compared to an Organisation for Economic Co-operation and Development (OECD) average of 9\% 3 . Strikingly, the market-driven system in the U.S. generates tremendous waste on billing, marketing, administration, corruption, and profits. Overhead consumes 31 percent of U.S. health spending, including 25.3 percent of hospital spending 4 .

Although 17 million people have gained coverage under Obamacare since 2014, nearly 30 million U.S. adults still have no health insurance at all, and 31 million more are underinsured, together comprising approximately $40 \%$ of adults under age 65 5. The problems of coverage gaps, high out-of-pocket-costs, and spiraling costs particularly for medications, with several new
Anne-Emanuelle Birn 1 Ida Hellander ${ }^{2}$

drugs costing more than US\$100,000 per treatment - persist.

Despite over a century of political struggle, the United States is the only high-income country that does not provide universal health insurance to its population. Analysts have ascribed the problem, variously, to stakeholders with deep pockets and armies of lobbyists (and investors), deep-seated individualist values, and the absence of a labor party that mobilizes around working class needs. Amidst the misery of the 1930s Depression, national health insurance was excluded from social security legislation by a powerful alliance of insurance companies, business interests, physician groups, and hospital associations; legislative efforts were again defeated in the 1940s, 1970s, and 1990s despite wide public support 6 .

The U.S.'s largely private employer-based health insurance system was cemented during World War II, when mobilization of millions of soldiers left a shortage of workers, and the federal government encouraged companies to attract workers with insurance benefits (since wage controls precluded salary incentives). Unions later included these benefits in their bargaining packages. Meanwhile, insurance companies proliferated, becoming highly profitable.

Significant, if segmented, gains came in 1965 with government health plans for senior citizens and persons with low incomes, neither covered by workplace insurance. Medicare, a quasi-single 
payer system, currently serves 54 million people: those over 65 (regardless of income), people with end-stage renal disease, and permanently disabled persons under 65. Funded through taxes, premiums, and out-of-pocket cost-sharing (deductibles and coinsurance), Medicare includes medical (covering outpatient and preventive services) and hospital (including inpatient acute care, short-term nursing care, and hospice stays) insurance plans, both based on private-sector delivery. Medicare's privately-administered plans have inflated costs by US $\$ 280$ billion since 19857 . Medicare is one of the most popular social programs in the U.S., after social security, and has been well-funded, in large part because it is universal, with poor and better-off seniors in the same system, although today its benefits are inadequate, leaving seniors with average out-ofpocket spending of US $\$ 4,500$ annually.

A less well-funded government program, Medicaid, provides public insurance for lowincome individuals, covering some 70 million people at some point during the year. With federal co-financing and broad guidelines, each state operates its own system, resulting in varying eligibility criteria, coverage, and quality. Although $70 \%$ of Medicaid beneficiaries are poor children and (primarily) working parents, including pregnant women, most Medicaid spending is concentrated on the acute and long-term care needs of persons with disabilities and low-income senior citizens. A separate state-based Children's Health Insurance Program (CHIP) was established in 1997 and covers 8 million children (and in some states, parents) in low-income families above the poverty line who are not Medicaid eligible.

Together, Medicare and Medicaid cover over one-third of the population and account for almost half of U.S. healthcare expenditures (but the U.S. colony/possession of Puerto Rico, with $60 \%$ of its population insured by these two programs, receives far lower reimbursement from the federal government than do the 50 states). There are also public systems for veterans, indigenous populations, and prisoners, and publiclyfunded private insurance for members of Congress, government employees, and the military. Underfunded public hospitals, and community and free clinics are available in some settings. About half of working-age Americans have employer-based insurance, and businesses providing coverage receive tax subsidies of nearly US\$ 300 billion per year.

Altogether, about 64 percent of U.S. health expenditures are financed by taxes, around 17 percent by business, and the remaining $21 \%$ by households 8 . It is a myth that the U.S. has a privately-funded health system.
In the 1990s, with health care expenditures climbing to over $12 \%$ of GDP, insurers implemented "managed care" in an attempt to control costs. Early managed care efforts emphasized prevention and primary care and attempted to reduce utilization of costly emergency and specialty care, tests, and treatments by requiring that these services be pre-authorized by a primary care doctor acting as a "gatekeeper". This experiment in cost control failed, and insurers subsequently adopted new strategies to shift the cost of care to patients through higher deductibles, co-payments, and co-insurance, limiting the choice of provider to only those doctors and hospitals that accept deeply discounted fees.

With the uninsured soaring to 50 million people by 2010, pressure mounted for an overhaul. That year, the ACA became the largest health reform since 1965. The ACA mandates that individuals and employers with over 50 employees purchase health insurance, with financial penalties for noncompliance. It introduced health insurance exchanges - "online marketplaces" offering a range of subsidized (through tax credits) health insurance plans - for individuals and small businesses ${ }^{9}$. The ACA also expanded Medicaid funding to cover all people under age 65 at or below $138 \%$ of the federal poverty level, superseding other eligibility criteria. But 19 of 50 states have rejected this provision, leaving some 4 million poor people with neither Medicaid nor subsidized coverage, disproportionately affecting low-income racial minorities 10 .

The ACA includes various consumer protections aimed at preventing the most egregious health insurance abuses such as lifetime limits and "preexisting condition" exclusions, and requires insurers to cover preventive services (without cost-sharing) and a package of "essential" health benefits. But insurers have been able to skirt the regulations by limiting access to providers and costly medications (such as for HIV and other serious illnesses).

The ACA has not led to universal coverage - about $10 \%$ of the U.S. population is currently uninsured. Undocumented immigrants are excluded from the ACA exchanges and Medicaid, and nearly 500,000 legal immigrants lost their coverage in 2015 due to requirements for additional documentation. A major problem is that deductibles are so high for ACA plans (e.g. US\$ 10,000 for a family "bronze" plan and US $\$ 6,000$ for a family "silver" plan) that coverage is all but useless. In addition, many people who signed up for Obamacare in 2014 have dropped coverage as they cannot afford the premiums or think the coverage is not worth the cost. Moreover, for the approximately 150 million people with 
employment-based insurance, premiums and out-of-pocket costs are rising rapidly. Deductibles have risen seven times as fast as wages since 2000, and premiums have tripled 11 .

Access to care remains regulated by arcane contracts via 35 major insurers, each with dozens of subsidiaries and thousands of health plans. Over 350,000 insurance company employees (and hundreds of thousands of indirect workers) govern which of the country's nearly 900,000 physicians and surgeons and 5,700 hospitals can be accessed Uninsurance and underinsurance contribute to worse health outcomes for many conditions and increasingly to personal bankruptcy, half of which are due to medical debts.

Most importantly, even with increased public financing, the insurance industry's role in drafting the ACA has left the private sector in control of administering health coverage, not only for ACA health plans, but increasingly for traditionally publicly-administered plans like Medicare and Medicaid.

Indeed, health care after ACA remains an even more profitable capitalist enterprise than before, in part thanks to the half billion dollars spent by pharmaceutical and insurance firms on lobbying Congress each year. In 2010, the ten largest health insurance companies collectively cleared US\$ 12.7 billion in profits (not counting CEO salaries and stock options). In 2014, the largest health insurance company, UnitedHealth, made US\$ 10.3 billion in profits on revenues of US\$ 130.5 billion, a 7\% increase from 2013. At the same time, from 2010 through 2013, overall U.S. health care fraud resulted in US\$ 19.2 billion in fines (mostly imposed on drug companies for illegal marketing tactics), with US\$250-500 billion in health care spending lost to corruption annually, involving every aspect of the health sector 12 .

The majority of Americans have long supported a universal, single-tier health system; however, conservative forces would like to see ACA repealed and eschew the notion of health care as a right. While Obamacare has helped millions obtain health insurance and increases preventive coverage, it will not guarantee universality, and it entrenches a profit-based system. Ultimately, it won't solve the U.S. health care crisis (Figure 1).

Ironically, what the U.S. spends per capita through public financing alone exceeds total average health spending in OECD countries, suggesting that a fully publicly administered and financed system eliminating private insurers and reducing administrative overhead would be much more efficient and far less expensive than the U.S.'s current arrangement ${ }^{13}$. Instead, health care provision in the United States remains highly inequitable, demonstrating the limits to a market-based system.

Figure 1

Basic features of health care financing and delivery in the United States.

\footnotetext{
- Almost $2 / 3$ publicly (taxpayer) financed, but overwhelmingly administered and delivered through the private sector;

- Employer-based, private health insurance covers over half of the population, with significant public financing: employers receive tax subsidies for providing insurance, and $28 \%$ of employer-based insurance is for government employees, whose coverage is publicly financed;

- Government-funded but increasingly privately-administered system for the elderly and disabled (Medicare); separate public state-based systems for low-income groups (Medicaid, under mostly private administration); and a publicly financed and delivered system for veterans;

- Dominance of for-profit, market-driven health care plans via thousands of health plans, with a maze of incentives to purchase coverage (tax subsidies for employers and tax credits for individuals) and disincentives (penalties, high deductibles and coinsurance) for patients to access care;

- Coverage expanded through Obamacare's Medicaid expansion and subsidized private coverage, but 28.5 million remained uninsured in 2015 and employer-sponsored coverage is rapidly deteriorating.
} 


\section{Contributors}

A.-E. Birn conceived and wrote first draft and edited. I. Hellander edited extensively.
This article is adapted from Birn et al. 1 .
1. Birn A-E, Pillay Y, Holtz TH. Textbook of global health. 4th Ed. New York: Oxford University Press; in press.

2. Davis K, Stremikis K, Schoen C, Squires D. Mirror, mirror on the wall, 2014 update: how the performance of the U.S. Health Care System compares internationally. New York: The Commonwealth Fund; 2014.

3. Keehan SP, Cuckler GA, Sisko AM, Madison AJ, Smith SD, Stone DA, et al. National health expenditure projections, 2014-24: spending growth faster than recent trends. Health Aff 2015; 34:1407-17.

4. Himmelstein DU, Jun M, Busse R, Chevreul $\mathrm{K}$, Geissler A, Juerissen P, et al. A comparison of hospital administrative costs in eight nations: US costs exceed all others by far. Health Aff 2014; 33:1586-94.

5. Congressional Budget Office. Insurance coverage provisions of the affordable care act - CBO's March 2015 baseline. https://www.cbo.gov/sites/default/ files/cbofiles/attachments/43900-2015-03-ACAta bles.pdf (accessed on 25/Jan/2016).

6. Birn A-E, Brown T, Fee E, Lear W. Struggles for national health reform in the United States. Am J Public Health 2003; 93:86-91.

7. Hellander I, Himmelstein DU, Woolhandler S. Medicare overpayments to private plans, 19852012: shifting seniors to private plans has already cost Medicare $\$ 282.6$ billion. Int J Health Serv 2013; 43:305-19.
8. Himmelstein DU, Woolhandler S. The current and projected taxpayer shares of U.S. Health Costs. Am J Public Health 2016; 106:449-52.

9. Department of Health and Human Services. Key features of the Affordable Care Act by year. 2015. http://www.hhs.gov/healthcare/facts-and-fea tures/key-features-of-aca-by-year (accessed on 28/Apr/2015).

10. Artiga S, Stephens J, Damico A. The impact of the coverage gap in states not expanding Medicaid by race and ethnicity. http://kff.org/disparities-pol icy/issue-brief/the-impact-of-the-coverage-gapin-states-not-expanding-medicaid-by-race-andethnicity/ (accessed on 25/Jan/2016).

11. The Kaiser Family Foundation; Health Research and Educational Trust. Web briefing for media: Kaiser/HRET employer health benefits survey. http://kff.org/private-insurance/event/web-brief ing-for-media-2015-kaiser-hret-employer-healthbenefits-survey/ (accessed on 25/Jan/2016).

12. Geyman J. Growing bureaucracy and fraud in US health care. Huffington Post 2015; 12 dec. http:// www.huffingtonpost.com/john-geyman/growingbureaucracy-and-f_b_8750740.html (accessed on 25/Jan/2016)

13. Sullivan K. How to think clearly about Medicare administrative costs: data sources and measurement. J Health Polit Policy Law 2013; 38:479-504.

Submitted on 28/Jan/2016 Approved on 25/Feb/2016 